\title{
Effects of Apogee on Growth and Whole-canopy Photosynthesis in Spur 'Delicious' Apple Trees
}

\author{
D. Michael Glenn ${ }^{1}$ and Stephen S. Miller ${ }^{2}$ \\ U.S. Department of Agriculture, Agricultural Research Service, Appalachian \\ Fruit Research Station, 2217 Wiltshire Road, Kearneysville, WV 25430
}

Additional index words. Malus sylvestris var. domestica, growth regulator, vegetation control, fruit size, fruit number

\begin{abstract}
This study examines the effect of multiple spray applications of Apogee on shoot growth and whole-canopy photosynthesis (WCPn) rate in young, bearing apple trees. Apogee increased fruit numbers and reduced shoot growth and inconsistently reduced leaf area but the reduction in photosynthetic area did not result in reduced WCPn or a detrimental effect on the fruit number:fruit size relationship. Since WCPn was not affected when leaf area was reduced by Apogee treatment, it suggests a greater photosynthetic efficiency of leaves on Apogee treated trees due to reduced shading. The use of Apogee for canopy management may produce a side-effect of increasing fruit set, which may be managed through a crop thinning program.
\end{abstract}

Vegetative growth management is essential in a modern high density apple planting. Rootstocks are commonly used to dwarf the tree and facilitate higher density plantings. However, dwarfing rootstocks may not suppress shoot extension growth, eventually resulting in overcrowding in the orchard. Excess vegetative growth and overcrowding reduce light and spray penetration into the canopy, which lowers fruit quality and may reduce return bloom. In addition pruning costs are increased by excessive vegetative growth.

Plant growth regulators have been used since the 1960s (Miller, 1988) to inhibit shoot elongation and help maintain apple tree canopies within the allotted planting space. Daminozide and ethephon are two growth regulators that received widespread attention and use for growth control in apple during the late 1960s and 1970s (Miller, 1988). Later work with triazole derivatives, such as paclobutrazol and uniconazole, demonstrated that these compounds had strong vegetative growth controlling properties in apple (Davis and Curry, 1991). Registration for the use of daminozide to control vegetative growth in apple was cancelled in 1989 because of controversial health issues and environmental concerns. Ethephon has not been registered for growth control in bearing apple trees because of problems with fruit abscission (Byers, 1993). Paclobutrazol was not registered for tree fruit crops in the U.S. because of concerns related to the strong residual nature of the compound.

Recently, a new class of compounds, the acylcyclohexanediones, has been shown to exhibit strong shoot growth inhibiting properties (Rademacher et al., 1992). Like daminozide and paclobutrazol, these compounds inhibit the production of growth-active gibberellins,

Received for publication 20 May 2004. Accepted for publication 3 Sept. 2004.

'Soil scientist; e-mailmglenn@afrs.ars.usda.gov. ${ }^{2}$ Horticulturist. thereby retarding shoot elongation. Prohexadione-calcium (Apogee), a compound in this class, has demonstrated excellent vegetative growth controlling properties in a number of plant species (Miyazawa et al., 1991) including apple(Evans etal., 1999; Greene, 1999; Miller, 2002; Unrath, 1999). Growth response to foliar sprays of Apogee is visible in apple shoots about 10 to $14 \mathrm{~d}$ after application (Greene, 1999), with response to a single application lasting about 3 to 4 weeks (Evans et al., 1997; Unrath, 1999). In addition to retarding shoot growth in apple, Apogee has been reported to increase fruit set (Greene, 1999; Unrath, 1999).

Only limited attention has been given to the physiological effects of Apogee on apple trees. Owens and Stover (1999) applied Apo- gee in the fall to young 'Golden Delicious' trees growing in the nursery and increased nonstructural carbohydrates and $\mathrm{N}$ levels in shoots. Similar treatments to 'Fuji' had no effect on carbohydrates but did increase $\mathrm{N}$ levels. Guak et al. (2001) reported an increase in total nonstructural carbohydrates, primarily starch, in Apogee treated M.26 rootstock liners. Apogee also reduced the total leaf area formed after treatment, but increased specific leaf weight (Guak et al., 2001). Steffens et al. (1985) reported a similar effect on specific leaf weight when apple seedlings were grown in a nutrient solution supplied with the growth regulator paclobutrazol. When paclobutrazol was applied as a soil drench or brushed onto the stems of 1-year-old 'Delicious' apple trees grown in the greenhouse, leaf area and leaf dry weight were reduced (Wieland and Wample, 1985). The soil drench treatment at $150 \mathrm{mg}$ per plant reduced specific leaf weight, while stem treatments at 25 or $50 \mathrm{mg}$ per plant increased specific leaf weight and soluble carbohydrate levels.

Guak et al. (2001) found that M.26 apple plants treated with $250 \mathrm{mg} \cdot \mathrm{L}^{-1}$ Apogee had a lower leaf stomatal conductance $\left(\mathrm{g}_{\mathrm{s}}\right) 17 \mathrm{~d}$ after treatment compared to control plants. They attributed the decline in $g_{s}$, which occurred mainly in the early afternoon hours, to a possible feedback inhibition of photosynthesis (Pn) caused by the buildup of starch in the Apogee treated plants. In contrast DeJong and Doyle (1984) reported an increase in leaf $g_{s}$ from paclobutrazol applied to mature nectarine trees under field conditions. Leaf Pn was not affected by the paclobutrazol treatment, but because leaf area was reduced they suggested that WCPn might be reduced.

Changes in leaf thickness (Shiqin et al., 1991) and chlorophyll content (Halfacre et al., 1968; Shiqin et al., 1991; Steffens and Wang, 1984) coupled with increases in flowering

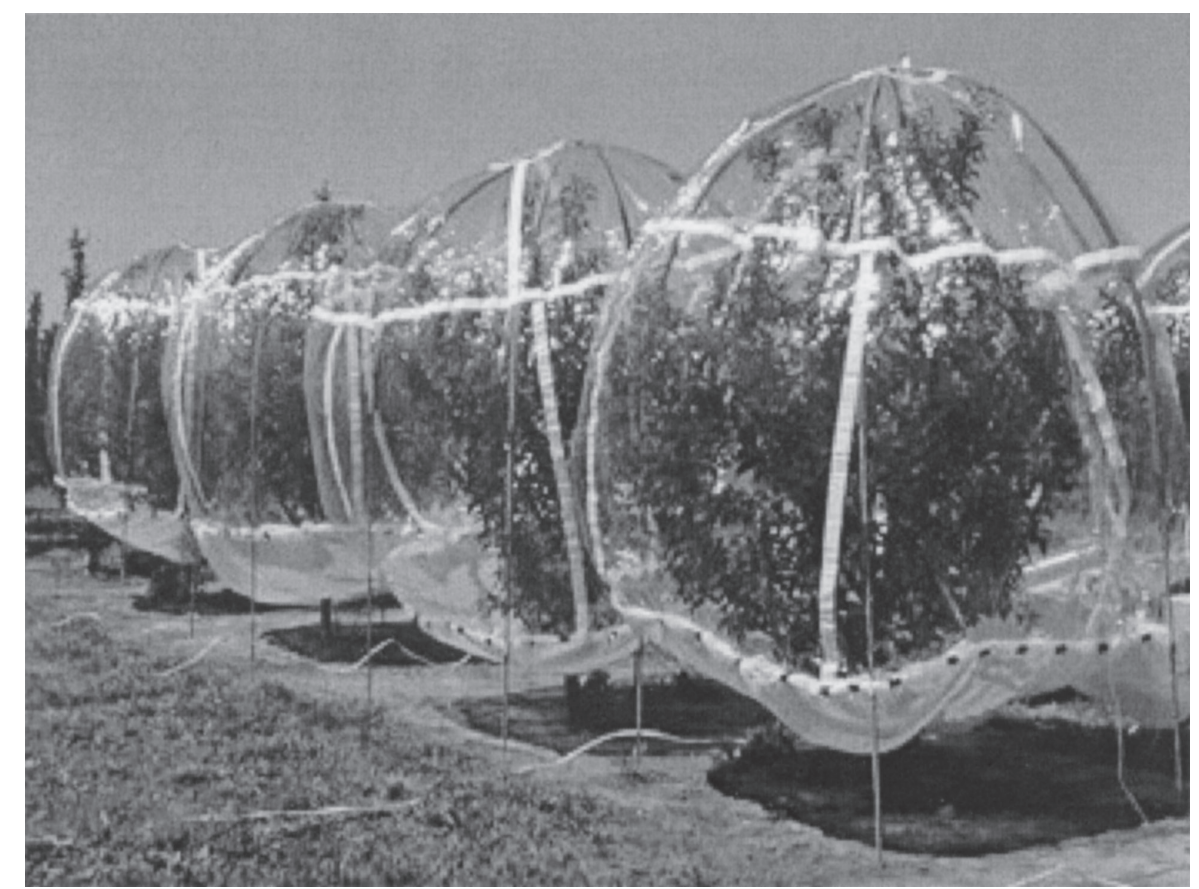

Fig. 1. Whole canopy photosynthesis chambers enclosing apple trees. 
(Batjer et al., 1964; Byers, 1993; Edgerton and Hoffman, 1965; Williams, 1972) and yields (Williams, 1972) following treatment with various growth retardants suggest a possible increase in apple tree Pn. However, data supporting this thesis are limited. Halfacre et al. (1968) reported reduced Pn when potted 1-year-old apple trees were sprayed with 1000 to $4000 \mathrm{mg} \cdot \mathrm{L}^{-1}$ daminozide. Dozier and Barden (1971) found no effect of ethephon on net Pn of greenhouse grown apple trees when sprayed at rates up to $4000 \mathrm{mg} \cdot \mathrm{L}^{-1}$. Ferree and Hall (1978) reported that a single application of daminozide $\left(2000 \mathrm{mg} \cdot \mathrm{L}^{-1}\right)$ or ethephon $\left(1000 \mathrm{mg} \cdot \mathrm{L}^{-1}\right)$ had no effect on the Pn or transpiration of leaves of potted apple trees grown in a growth chamber. Wieland and Wample(1985) reported no significant effect on Pn rate or transpiration rate from soil or stem applied paclobutrazol. In contrast, Huang et al. (1995) increased spur leaf Pn in 4-year-old 'Aki Fuji' apple trees grown in the field and treated with soil-applied paclobutrazol. They partially attributed the increased Pn to higher light levels within the canopy that resulted from the growth retarding effect of paclobutrazol. Working with uniconazole, another triazole growth regulator, Steffens and Zimmerman (1992) reported a seasonal increase in Pn of young tissue-cultured and budded apple trees. There were no differences in Pn between foliar spray applications or soil trunk drench treatments. Apogee treatments increased whole canopy photosynthesis (WCPn) of 2-year-old potted apple trees in 2 of 3 years and increased water use efficiency in 1 of 3 years (Sabatini et al., 2003).

The objectives of this study were to examine the effect of multiple spray applications of Apogee on shoot growth and WCPn rate in young bearing apple trees.

\section{Materials and Methods}

Five-year-old 'Washington Spur Delicious' apple trees on Malling Merton111 (MM.111) rootstock growing at the Appalachian Fruit Research Station, Kearneysville, W.Va., were used for this study. Trees were planted at a spacing of $3 \times 5.5 \mathrm{~m}$, trained to a central leader form, and had cropped the season prior to the initiation of experimental treatments. Ten trees of uniform size and vigor were selected for treatment in 2000. Five trees were sprayed with Apogee 27.5 DF (BASF Corp., Research Triangle Park, N.C.) and five trees were designated as nonsprayed controls. Three Apogee sprays were applied beginning at petal fall and repeated at 2-week intervals. Treatments were repeated on a different set of trees in 2001. Sprays were applied at a rate of 45 g Apogee 27.5 DF per 100 L (equivalent to a $6 \mathrm{oz} . / 100$ gal label rate) of spray solution adjusted for tree-row-volume of canopy per hectare (Sutton and Unrath, 1984). The calculated tree-row-volume for the test block was $1309 \mathrm{~L} \cdot \mathrm{ha}^{-1}$ (140 gal/acre) in 2000 and $1785 \mathrm{~L} \cdot \mathrm{ha}^{-1}$ (191 gal/acre) in 2001. The final Apogee rate applied was $593 \mathrm{~g} \cdot \mathrm{ha}^{-1}$ in 2000 and $721 \mathrm{~g} \cdot \mathrm{ha}^{-1}$ in 2001. Actual spray volume applied to achieve wetness ranged from 704 to $728 \mathrm{~L} \cdot \mathrm{ha}^{-1}$. A nonionic adjuvant, Regulaid (Kalo Inc., Overland Park, Kan.), was included in all sprays at $0.125 \%(\mathrm{v} / \mathrm{v})$ along with spray grade ammonium sulfate (AMS) as a water conditioner on a weight basis equivalent to the weight of Apogee in the spray solution. The final spray solution was adjusted to $\mathrm{pH}$ 6.3 with distilled white vinegar (National Fruit Products Co., Winchester, Va.). Sprays were applied with a backpack hand-wand sprayer to wet the tree to the point of spray drip. Treatments were arranged in a randomized complete block design with five replications.

Trees were harvested when most fruit reached a commercially acceptable stage of maturity based on starch index rating, soluble solids concentration and flesh firmness. The number of fruit harvested, total weight of fruit, and diameter of fruit were recorded from each tree. Mean shoot growth was determined by measuring 20 terminal shoots per tree at the end of the growing season. Fruit were also harvested in 2002, in which no treatments were applied, to evaluate any carryover effects. Terminal shoot length, fruit number per tree, yield per tree and mean fruit diameter were analyzed using the completely randomized block design $(P=0.05)$. Analysis of covariance was used to evaluate the treatment effect on fruit size using fruit number as the covariate, pooled for all years. No significant differences were indicated in the analysis of covariance, so a pooled regression was calculated.

Whole canopy photosynthesis chamber. The whole canopy photosynthesis chamber (Fig. 1) was constructed of 0.08-mm (3-mil) polyester film (Mylar Type D; Dupont, Wilmington, Del.). Six vertical panels were attached with Velcro tape to a circular top. The bottom was constructed from an oversized square of $0.15-\mathrm{mm}$ (6-mil) polyethylene plastic that was rolled up with the Mylar sides and then clamped every $15 \mathrm{~cm}$. The bottom panel had a radial cut to insert the tree and was sealed with Velcro. The bottom panel was tied to the tree for a tight fit at a point immediately below the first scaffold branch, generally 30 to $50 \mathrm{~cm}$ above the soil. The top and bottom panels were $2.1 \mathrm{~m}$ in diameter and the vertical panels were $2.1 \mathrm{~m}$ high, resulting in a volume of $7.5 \mathrm{~m}^{3}$.

A hoop structure of 13-mm electrical conduit was erected over each tree. Four components of the structure were joined together at the apex of the tree and the four conduit legs were attached to steel rods, hammered into the soil at the perimeter of the tree. The mylar chamber was placed over the metal conduit structure. The vertical panels and the bottom panel were gathered and folded around the metal structure. The outlet port was a $30-\mathrm{cm}$ hole in the top panel.

Air was forced into the chamber with a one horsepower fan attached to a metal conduit with a cross-sectional area of $777 \mathrm{~cm}^{2}$. Five holes were drilled in the conduit to measure air velocity with a velometer (model 6000-P; Alnor Instruments, Skokie, Ill.) and ten 2.5-cm positions at each sample port were measured at the beginning and end of the sampling period. The velocity data were averaged to calculate mass air flux. Air was forced into the chamber by inserting the conduit into the seam of two vertical panels and the bottom panel. The conduit was kept horizontal by elevating the fan and conduit housing. Leaf movement was visually assessed to insure no large eddies developed in the chamber. About three chamber volumes were exchanged per minute. Air temperature was measured with a shielded thermocouple hanging about $30 \mathrm{~cm}$ into the chamber through the outlet port. Whole canopy net $\mathrm{CO}_{2}$ and $\mathrm{H}_{2} \mathrm{O}$ exchange was measured with an infrared gas analyzer (CIRAS-1, PP Systems, Haverhill, Mass.) from the difference in $\mathrm{CO}_{2}$ and $\mathrm{H}_{2} \mathrm{O}$ concentration between the inlet (reference) and the outlet (analysis) ports of each chamber. Equal lengths of tubing were inserted into the conduit and the outlet port, and the sampled air was drawn to the IRGA with a pump. Response time was 10 to $15 \mathrm{~s}$. The sampled air was blown into a cylinder that was sampled by the IRGA with its own sampling pumps. Multiple chambers were sampled sequentially every 10 min using a programmable controller (SDM-CD16AC; Campbell Scientific, Logan, Utah) that controlled solenoid valves on the reference and analysis tubes of each chamber. The controller was programmed and data collected with a datalogger (CR-7; Campbell Scientific).

Data were collected from 0900 to 1500 HR on the following dates: 2000: 8 and 26 May; 20 June; 6 July; 2001: 26 June; 27 July; and 19 Sept.

Following harvest all trees were covered with a netting to capture all the leaves when they abscised. The leaves were collected and air-dried at $80^{\circ} \mathrm{C}$ for $96 \mathrm{~h}$. At the time of sampling, a subsample of about $3 \mathrm{~kg}$ fresh weight was separated, the leaf area was measured, and the ratio of air-dried weight to leaf area was calculated. This ratio was used to convert the total air-dried weight of each tree to total leaf area. Leaf area index was the quotient of the total leaf area divided by the area of the canopy shadow measured within one hour of solar noon in September.

Light interception. Photosynthetic photon flux $(P P F)$ was measured at a weather station about $200 \mathrm{~m}$ from the measurement site with a quantum sensor (model 190SA; LI-COR, Lincoln, Nebr.). In addition, photosynthetically active radiation $(P A R)$ interception by the tree canopy sampled for whole canopy gas exchange was measured with a line quantum sensor (191SA; LI-COR) within one hour of solar noon, 1 to $2 \mathrm{~d}$ before or after sampling. Incoming PAR was measured above the canopy and then the sensor was placed below the canopy at eight locations radiating from the trunk to the edge of the shadow cast by the canopy. Interception was the quotient of mean PAR below the canopy divided by the incoming PAR. The average diameter of the canopy shadow was measured and total $P A R$ interception (moles $P A R$ per tree for the time period) was the product of canopy area $\left(\mathrm{m}^{2}\right)$ $\times$ incoming $P A R\left(\mu \mathrm{mol} \cdot \mathrm{m}^{-2} \cdot \mathrm{s}^{-1}\right) \mathrm{x}$ interception (expressed as a fraction of 1$) \times$ period of sampling (seconds). WCPn $\left(\mathrm{CO}_{2} \mathrm{~g} /\right.$ tree $)$ for all years was analyzed using regression analysis with intercepted $P A R$ per tree as the 
Table 1. Effect of three prohexadione-calcium (Apogee) sprays on shoot growth, total yield, and fruit size in 5-year-old 'Washington Spur Delicious'/MM.111 apple trees.

\begin{tabular}{|c|c|c|c|c|}
\hline Treatment $^{2}$ & $\begin{array}{l}\text { Terminal shoot } \\
\text { length }(\mathrm{cm})\end{array}$ & $\begin{array}{l}\text { Number fruit } \\
\text { per tree }\end{array}$ & $\begin{array}{l}\text { Yield per } \\
\text { tree }(\mathrm{kg})\end{array}$ & $\begin{array}{l}\text { Mean fruit } \\
\text { diam }(\mathrm{cm})\end{array}$ \\
\hline \multicolumn{5}{|l|}{2000} \\
\hline Control & $50.0 \mathrm{a}^{\mathrm{y}}$ & $151 \mathrm{~b}$ & $33.1 \mathrm{a}$ & $8.2 \mathrm{a}$ \\
\hline Apogee & $24.6 \mathrm{~b}$ & $221 \mathrm{a}$ & $40.1 \mathrm{a}$ & $7.6 \mathrm{~b}$ \\
\hline \multicolumn{5}{|l|}{2001} \\
\hline Control & $66.6 \mathrm{a}$ & $146 \mathrm{~b}$ & $31.9 \mathrm{~b}$ & $7.6 \mathrm{a}$ \\
\hline Apogee & $21.4 \mathrm{~b}$ & $336 \mathrm{a}$ & $56.2 \mathrm{a}$ & $7.0 \mathrm{~b}$ \\
\hline
\end{tabular}

Initial spray applied at petal fall; two successive sprays applied at 2-week intervals. Apogee sprays applied at $45 \mathrm{~g} \cdot \mathrm{L}^{-1}$ based on canopy tree-row-volume.

${ }^{y}$ Mean separation within columns for year by Duncan's new multiple range test $P \leq 0.05$.

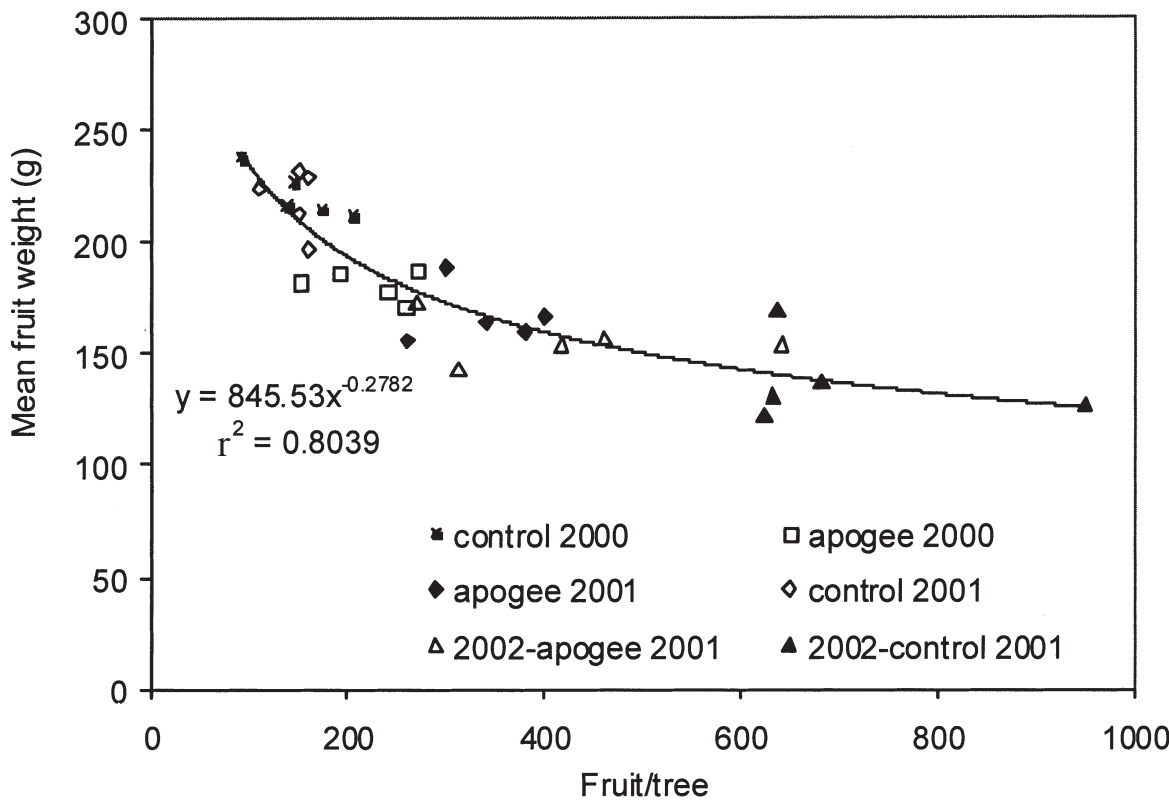

Fig. 2. Effect of three prohexadione-calcium (Apogee) sprays on the relationship of average fruit weight and fruit number in 5-year-old 'Washington Spur Delicious'/MM.111 apple trees during three growing seasons.

Table 2. Effect of three prohexadione-calcium (Apogee) sprays on shoot leaf area and leaf area index in 5-year-old 'Washington Spur Delicious'/MM.111 apple trees.

\begin{tabular}{llllll}
\hline & \multicolumn{2}{c}{$\begin{array}{c}\text { Leaf area } \\
\left(\mathrm{m}^{2}\right)\end{array}$} & & \multicolumn{2}{c}{$\begin{array}{c}\text { Leaf area } \\
\text { index }\end{array}$} \\
\cline { 2 - 3 } \cline { 5 - 6 } Treatment & 2000 & 2001 & & 2000 & 2001 \\
\hline Apogee $^{z}$ & 14.9 & 14.5 & & 2.43 & 2.31 \\
Control & $22.6^{*}$ & 16.6 & & $3.35^{*}$ & 2.60 \\
\hline
\end{tabular}

${ }^{2}$ Apogee $27.5 \mathrm{DF}$ foliar sprays $(45 \mathrm{~g} / 100 \mathrm{~L}$ adjusted for tree-row-volume) applied at petal fall and repeated twice at 2-week intervals.

"Mean separation within columns based on $t$ test, $P \leq 0.05$.

independent variable. Slope and intercept of the regression relationship were tested $(P<$ 0.05 ) for the 0900 to $1500 \mathrm{HR}$ period and the 1200 to $1400 \mathrm{HR}$ period and the two time periods were tested.

Carbon-13 isotope discrimination. Ten debudded shoots/tree of previous season shoots were collected in the fall of 2000 and 2001 . The tissue was dried at $60^{\circ} \mathrm{C}$ for $72 \mathrm{~h}$, ground, and analyzed for carbon-13 content and carbon-13 discrimination $(\Delta)$ by Isotope Services (Los Alamos, N.M.). Isotopic discrimination was calculated according to Farquhar et al.,(1989). The isotopic composition of carbon dioxide in air $\left(\delta{ }^{13} C_{\text {air }}\right)$ was assumed to be -7.8 parts per thousand (Francey et al., 1995). Data were analyzed in a randomized complete block design by year with ANOVA $(P<0.05)$. There was no difference due to year so the treatment data were pooled.

\section{Results and Discussion}

Three Apogee sprays, beginning at petal fall and continued at 2-week intervals, reduced shoot growth in 'Washington Spur Delicious'/MM.111 apple trees in each of the two years (Table 1). Apogee sprays reduced terminal shoot extension growth an average of $59 \%$ compared to controls. This level of shoot growth suppression is similar to that reported previously by Miller (2002) and by others (Byers and Yoder, 1999; Greene, 1999) for field grown apple trees treated at a similar rate. Fruit set, based on the number of fruit per tree at harvest, increased in Apogee treated trees in both years (Table 1). In the present study fruit size was also decreased by Apogee treatment (Table 1), however the relationship of fruit number to fruit size indicated no significant difference due to Apogee treatment (Fig. 2) in 2000, 2001 or 2002 when no treatments were applied. Greene (1999) reported that fruit set on 'McIntosh' increased and fruit size decreased linearly with increasing prohexadi-
one-Ca (Apogee) concentration. Unrath (1999) reported an increase in fruit set on 'Delicious' when $250 \mathrm{mg} \cdot \mathrm{L}^{-1}$ prohexadione-Ca was applied at 0,7 , or $14 \mathrm{~d}$ after petal fall, but not when applied at $21 \mathrm{~d}$ after petal fall. While increased fruit set has been more commonly associated with the higher rates of Apogee $\left(250 \mathrm{mg} \cdot \mathrm{L}^{-1}\right)$, increased fruit set has also been noted at a lower rate $\left(125 \mathrm{mg} \cdot \mathrm{L}^{-1}\right)$ (Greene and Autio, 2002). Total yield was slightly, but not significantly greater with Apogee sprays in 2000 and yields per tree were increased on Apogee treated trees in 2001. Apogee had no effect on the length to diameter (L/D) fruit ratio or percent surface red color (data not shown).

Apogee application reduced leaf area and leaf area index in 2000 but not in 2001 (Table 2). Our findings agree with Guak et al. (2001), who reported a reduction in total leaf area of potted M.26 trees from a single Apogee spray applied from 125 to $500 \mathrm{mg} \cdot \mathrm{L}^{-1}$. Specific leaf weight was not affected by the treatments $\left(12.0\right.$ and $12.5 \mathrm{mg} \cdot \mathrm{cm}^{-2}$ for treated and control, respectively, pooled for both years), indicating no morphological effect on leaf structure. These specific leaf weight results are in contrast to those reported by Guak et al. (2001), however, their studies utilized potted M.26 liners and not field grown trees as in this study. Apogee increased water use efficiency (WUE) one of 3 years in potted apples (Sabatini et al. 2003). In the present study, isotopic carbon discrimination indicated no treatment effect (19.46 vs. 19.60 for treated and control respectively, pooled for both years). Isotopic carbon discrimination results indicate that the Apogee treatments did not affect WUE of the trees. Isotopic discrimination of carbon-13 is a method of measuring season-long WUE. Isotopic discrimination of carbon-13 has been correlated with WUE in field crops (Ehleringer, 1993; Farquhar and Richards, 1984; Farquhar et al., 1989) and tree fruit crops (Bongi et al., 1994; Glenn et al., 2000, 2003).

Most studies designed to examine the effect of vegetative growth retardants on fruit tree Pn have used potted trees grown in a greenhouse (Dozier and Barden, 1971; Ferree and Hall, 1978; Guak et al., 2001; Sabatini et al. 2003; Wieland and Wample, 1985). In addition, these greenhouse studies and reported field studies (DeJong and Doyle, 1984; Sabatini et al. 2003; Steffens and Zimmerman, 1992) have focused on single leaf Pn measurements rather than WCPn measurements. In the present study, whole canopy Pn measurements offield grown apple trees indicated that there were no differences $(P \leq 0.05)$ between treatments, years, or time of day (Fig. 3). Despite the reduced leaf area and LAI of Apogee treated trees in 2000, no effect on WCPn was measured at any date. In several of the previous studies with growth retardants [ethephon (Dozier and Barden, 1971) and paclobutrazol (DeJong and Doyle, 1984; Steffens and Zimmerman, 1992)], when the authors found no effect on Pn rate, they suggested that WCPn may be reduced because of the reduction in leaf area. In the present study, we did not find this prediction to be true. Overall, the partitioning of carbon to fruit was not altered by the Apogee treatments 


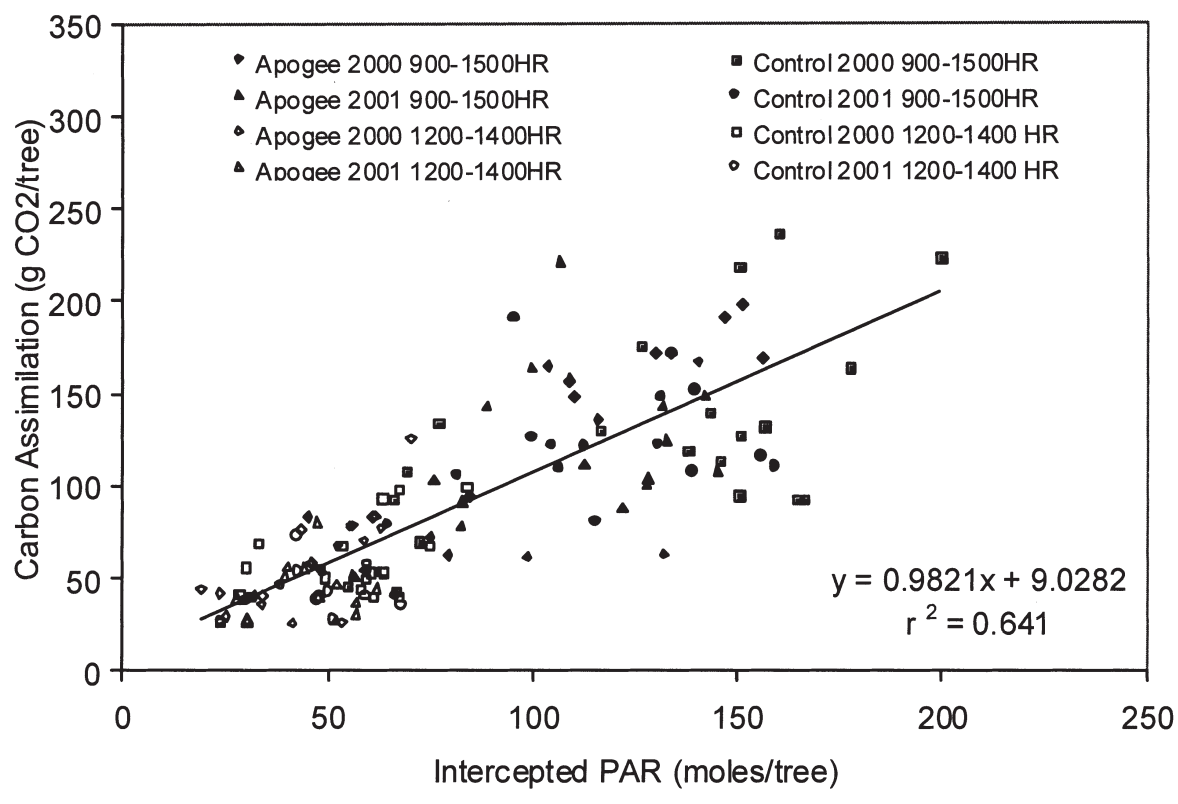

Fig. 3. Relationship of whole canopy carbon assimilation to intercepted photosynthetically active radiation (PAR) for 5-year-old field-grown 'Washington Spur Delicious'/MM.111 apple trees treated in 2000 and 2001.

(Fig. 2) and there was no carry-over effect on fruit size in 2002.

In conclusion, the application of Apogee increased fruit set, as demonstrated by others, which may increase the potential for alternate bearing. Our results indicate that the effect of Apogee on fruit size is likely due to increased fruit numbers and not a direct effect of the Apogee spray. Apogee consistently reduced shoot growth and inconsistently reduced leaf area, but the reduction in photosynthetic area did not result in reduced WCPn or a detrimental effect on the fruit number:fruit size relationship. Since WCPn was not affected when leaf area was reduced by Apogee treatment, it suggests a greater photosynthetic efficiency of leaves on Apogee treated trees due to reduced shading. The use of Apogee for canopy management may have a side-effect of increasing fruit set, which may be managed through a crop thinning program.

\section{Literature Cited}

Bongi, G., A. Palliotti, P. Rocchi, and G. Roselli. 1994. Evaluation of WUE in peach grafted on different interspecific hybrid rootstocks. Plant Physiol. Biochem. 32:149-157.

Batjer, L.P., M.W. Williams, and G.C. Martin. 1964. Effects of N-dimethyl amino succinamic acid (B-nine) on vegetative and fruit characteristics of apples, pears, and sweet cherries. Proc. Amer. Soc. Hort. Sci. 85:11-16.

Byers, R.E. 1993. Controlling growth of bearing apple trees with ethephon. HortScience 28:1103-1105.

Byers, R.E. and K.S. Yoder. 1999. Prohexadionecalcium inhibits apple, but not peach, tree growth, but has little influence on apple fruit thinning or quality. HortScience 34:1205-1209.

DeJong, T.M. and J.F. Doyle. 1984. Leaf gas exchange and growth responses of mature 'Fantasia' nectarine trees to paclobutrazol. J. Amer. Soc. Hort. Sci. 109:878-882.

Davis, T.D. and E.A. Curry. 1991. Chemical regulation of vegetative growth. Critical Rev. Plant Sci. 10(2):151-188.
Dozier, Jr., W.A. and J.A. Barden. 1971. Net photosynthesis and respiration of apple leaves influenced by (2-chloroethyl)phosphonic acid. J. Amer. Soc. Hort. Sci. 96:789-790.

Edgerton, L.J. and M.B. Hoffman. 1965. Some physiological responses of apple to N-dimethyl amino succinamic acid and other growth regulators. Proc. Amer. Soc. Hort. Sci. 86:28-36.

Ehleringer, J.R. 1993. Variation in leaf carbon isotope discrimination in Encelia farinosa: Implications for growth, competition and drought survival. Oecologia 95:340-346.

Evans, R.R., J.R. Evans, and W. Rademacher. 1997. prohexadione calcium for suppression of vegetative growth in eastern apples. Acta Hort. 451:663-666.

Evans, J.R., R.R. Evans, C.L. Regusci, and W. Rademacher. 1999. Mode of action, metabolism, and uptake of BAS $125 \mathrm{~W}$, prohexadione-calcium. HortScience 34:1200-1201.

Farquhar, G.D., J.R. Ehleringer, and K.T. Hubick. 1989. Carbon isotope discrimination and photosynthesis. Annu. Rev. Plant Physiol. Mol. Biol. 40:503-537.

Farquhar, G.D. and R.A. Richards. 1984. Isotopic composition of plant carbon correlates with water-use efficiency of wheat genotypes. Austral. J. Plant Physiol. 11:539-552.

Ferree, D.C. and F.R. Hall. 1978. Effects of growth regulators and multiple applications of pesticides on net photosynthesis and transpiration of greenhouse-grown apple trees. J. Amer. Soc. Hort. Sci. 103:61-64.

Francey, U.J., P.P. Tans, C.E. Allison, I.G. Enting, J.W.C. White, and M. Troller. 1995. Changes in oceanic and terrestrial carbon uptake since 1982. Nature 373:326-330.

Glenn, D.M.,A. Erez, G. J. Puterka, and P. Gundrum. 2003. Particle films affect carbon assimilation and yield in 'Empire' apple. J. Amer. Soc. Hort. Sci. 128:356-362.

Glenn, D.M., R. Scorza, and C. Bassett. 2000. Physiological and morphological traits associated with increased water use efficiency in the willow-leaf peach. HortSci. 35:1241-1243.

Greene, D.W. 1999. Tree growth management and fruit quality of apple trees treated with prohexadione-calcium (BAS 125). HortScience 34:1209-1212.
Greene, D.W. and W.R. Autio. 2002. Apogee ${ }^{\circledR}$-A new growth retardant for apples. Univ. Mass. Ext. Factsheet F-127R.

Guak, S., D. Neilsen, and N.E. Looney. 2001. Growth, allocation of $\mathrm{N}$ and carbohydrates, and stomatal conductance of greenhouse grown apple treated with prohexadione-Ca and gibberellins. J. Hort. Sci. Biotechnol. 76:746-752.

Halfacre, R.G., J.A. Barden, and H.A. Rollins, Jr. 1968. Effects of alar on morphology, chlorophyll content, and net $\mathrm{CO}_{2}$ assimilation rate of young apple trees. Proc. Amer. Soc. Hort. Sci. 93:40-52.

Huang, W.D., T. Shen, Z.H. Han, and S. Liu. 1995. Influence of paclobutrazol on photosynthesis rate and dry matter partitioning in the apple tree. $\mathrm{J}$ Plant Nutr. 18:901-910.

Miller, S.S. 1988. Plant bioregulators in apple and pear culture. Hort. Rev. 10:309-401.

Miller, S.S. 2002. Prohexadione-calcium controls vegetative shoot growth in apple. J. Tree Fruit Prod. 3(1):11-28.

Miyazawa, T., K. Yanagisawa, S. Shigematsu, K. Motojima, and M. Matsuzawa. 1991. Prohexadione-calcium, a new plant growth regulator for cerals and ornamental plants, p.967-972. Brighton Crop protection Conference-Weeds. The British Crop Protection Council, Farnham.

Owens, C.L. and E. Stover. 1999. Vegetative growth and flowering of young apple trees in response to prohexadione-calcium. HortScience 34:1194-1196.

Rademacher, W., K.E. Temple-Smith, D.L. Griggs, and P. Hedden. 1992. The mode of action of acylcyclohexanediones-A new type of growth retardant, p. 571-577. In: C.M. Karssen, L.C. van Loon, and D. Vreugdenhil (eds.). Progress in plant growth regulation. Kluwer Academic Publ., Dordrecht, The Netherlands.

Sabatini, E., M. Noferini, G. Fiori, L. Corelli Grappadelli, and G. Costa. 2003. Prohexadione-Ca positively affects gas exchanges and chlorophyll content of apple and pear trees. Euro. J. Hort. Sci 68:123-128.

Shiqin, H., Y.Hui, and S.Zhimin. 1991. Physiological changes induced by paclobutrazol in 'Delicious' apple. Fruit Sci. Rpt. 18(4):163-172.

Steffens, G.L. and S.Y. Wang. 1984. Physiological changes induced by paclobutrazol (PP333) in apple. Acta Hort. 146:135-142.

Steffens, G.L. and R.H. Zimmerman. 1992. Influences of uniconizole on growth, fruiting, and photosynthetic activity of tissue culture-propagated own-rooted apple trees. Scientia Hort. 52:201-214.

Steffens, G.L., S.Y. Wang, M. Faust, and JU.K. Byun. 1985. Growth, carbohydrate, and mineral element status of shoot and spur leaves and fruit of 'Spartan' apple trees treated with paclobutrazol. J. Amer. Soc. Hort. Sci. 110:850-855.

Sutton, T.B. and C.R. Unrath. 1984. Evaluation of the tree-row-volume concept with density adjustments in relation to spray deposits in apple orchards. Plant Dis. 68:480-484.

Unrath, C.R. 1999. Prohexadione-Ca: A promising chemical for controlling vegetative growth of apples. HortScience 34:1197-1200.

Wieland, W.F. and R.L. Wample. 1985. Effect of paclobutrazol on growth, photosynthesis and carbohydrate content of 'Delicious' apples. Scientia Hort. 28:139-147.

Williams, M.W. 1972. Induction of spur and flower bud formation in young apple trees with chemical growth retardants. J. Amer. Soc. Hort. Sci 97:210-212. 